\title{
Dampak Psikologis Akibat Covid-19 pada Masyarakat Indonesia
}

\author{
Desi Wahyu Susilowati ${ }^{1}$ \\ ${ }^{1}$ RSJD Surakarta \\ Email: desi.ws89@gmail.com
}

\begin{abstract}
Covid-19 or Corona Virus Disease become an outbreak for the world, including Indonesia. People have been doing something to prevent Covid-19. Quarantine, social distancing, and keeping healthy is the government program to reduce the spread of Virus. This condition gives impact for everyone especially in psychology. This research aims to find correlation distress and obsessive compulsive disorder for pandemic. This research is quantitative research with correlational methods. The data have been collected from 157 subjects who are over twenty years old with distress and obsessive compulsive disorder scale. Data analysis method used is the product moment correlation from Pearson. The result showed that sign $(0.000)<a$ so that ignores Ho. There are correlations between distress and symptoms of obsessive compulsive disorder for pandemic situations.
\end{abstract}

Keyword: Covid -19, Distress, Obsessive-Compulsive Disorder

Abstrak. Covid 19 (Corona Virus Disease) telah menjadi bencana bagi seluruh negara di dunia, termasuk Indonesia. Berbagai cara dilakukan sebagai upaya untuk pencegahan penyebaran Covid 19, diantaranya: karantina, social distancing, dan menjaga kesehatan diri. Bencana ini memberikan dampak secara psikologis bagi setiap orang. Tujuan dari penelitian ini yaitu untuk mengetahui distress pada masyarakat Indonesia dan potensi munculnya gejala OCD (ObsessiveCompulsive Disorder) selama masa pandemik.

Jenis penelitian ini menggunakan design penelitian kuantitatif yang bersifat korelasional. Populasi dalam penelitian ini seluruhnya adalah warga negara Indonesia yang berusia diatas 20 tahun. Pemilihan subjek dilakukan dengan cara simple random sampling. Instrumen yang digunakan dalam penelitian ini yaitu skala dan dilakukan melalui internet.

Proses penelitian ini melibatkan 157 subjek yang dilakukan melalui internet. Hasil penelitian menunjukkan nilai sign $(0.000)<$ a dan angka korelasi sebesar $0.998>0.05$ sehingga Ho ditolak. Dengan demikian dapat disimpulkan bahwa terdapat hubungan distress dan gejala obsesi kompulsif selama masa pandemik.

Kata Kunci: Covid-19, Distress, OCD

\section{Pendahuluan}

Covid 19 (Corona Virus Disease) pertama kali terjadi di Wuhan, China, pada tahun 2019. Saat ini Covid 19 juga telah melanda Indonesia. WHO (2020) menyatakan bahwa Covid 19 sebagai bencana pandemik yang artinya bencana bagi seluruh negara di penjuru dunia. Hingga tanggal 01 Juli 2020, sebanyak 10. 748. 516 orang positif Covid 19 dan 523. 912 orang meninggal dunia karena Covid 19 (COVID-19 Corona virus outbreak, 2020). Kondisi dan situasi seperti saat ini tidak pernah terpikirkan oleh setiap orang. Hampir seluruh orang di dunia tidak siap (baik secara fisik maupun psikis) dalam menghadapi masa pandemic ini. Ketidaksiapan ini muncul dalam berbagai manifestasi perilaku yang berdampak pada psikologis. 
WHO (2020) menjelaskan bahwa upaya pencegahan penularan Covid 19 diantaranya melalui physical distancing, isolasi mandiri, dan karantina. Langkah pencegahan ini dilakukan secara global. Akan tetapi langkah ini bisa mempengaruhi kesehatan mental karena harus berpisah dengan orang-orang terdekatnya, serta hilangnya rasa kebebasan bagi sebagian orang (Brooks dkk, 2020). Selain itu, karantina juga bisa meningkatkan perasaan kesepian dan menurunkan minat sosial. Kondisi ini berisiko untuk menyebabkan seseorang mengalami gangguan mental misalnya : stres (Perrin dkk, 2009).

Penelitian yang dilakukan oleh Feng dkk (2020) menemukan bahwa Covid 19 menyebabkan distress bagi masayarakat umum. Distress ini merupakan bentuk pertahanan emosi seseorang akibat stres, yang terkadang muncul dalam bentuk depresi (misalnya: putus asa, sedih, dan kehilangan minat) dan kecemasan (misalnya: perasaan tegang) (Mazza dkk, 2020). Gejala lain bisa berupa rasa lelah yang ditandai dengan gejala somatik (misalnya: sakit kepala) yang muncul dapat berupa kelelahan dengan gejala somatik.

Wheaton (2007) menjelaskan bahwa distress dapat berpengaruh pada aktivitas kehidupan dan fungsi sosial seseorang. Distress juga kerap digunakan sebagai salah satu kriteria diagnostik dalam penegakkan gangguan jiwa (misalnya: obsessive compulsive disorder / OCD). Badri (2020) menjelaskan bahwa distress yang terlalu lama akibat covid 19 bisa menyebabkan seseorang mengembangkan obsessive compulsive disorder (OCD). Perilaku mencuci tangan yang awalnya disarankan oleh WHO sebagai bentuk pencegahan dapat berubah menjadi kompulsif. Seseorang akan mencuci tangannya terus-menerus dan berulang secara impulsive sebagai bentuk upaya mengatasi ketakutannya terhadap virus. Bentuk obsesi yang muncul tidak hanya ketakutan terhadap virus, namun juga kuman dan kotoran.

Obsessive compulsive disorder (selanjutnya ditulis OCD) adalah suatu gangguan yang ditandai dengan adanya pikiran (obsessive) dan perilaku (compulsive) yang berulang. Kompulsif adalah suatu perilaku atau tindakan berulang yang dirasakan sebagai bentuk keharusan. Misalnya: mencuci tangan, berdoa, memeriksa sesuatu berulang-ulang, menghitung, dll). Kompulsif muncul akibat adanya pikiran obsesif yang kuat sehingga mengganggu kehidupan sehari-hari atau stress. Sementara itu, obsesi adalah pikiran atau ide berulang dan terkadang sulit dikendalikan. Tema obsesi diantaranya: agresifitas, kekhawatiran akibat kontaminasi virus dan kuman, sexual, keamanan, agama, bentuk otot, somatik, dll. Obsesi juga dapat mengakibatkan distress karena muncul secara persisten dan berulang (APA, 2000; dalam Nevid dkk 2005).

Berdasarkan penjelasan mengenai dampak Covid 19 di atas, maka penelitian ini bertujuan untuk mengetahui dampak Covid 19 terhadap distress pada masyarakat Indonesia dan prevalensi munculnya gejala OCD. Hipotesis yang diajukan oleh peneliti yaitu Covid 19 menyebabkan distress sehingga memunculkan prevalensi seseorang mengalami OCD. Penelitian 
ini tidak ditujukan sebagai penegakkan diagnosa OCD karena tidak melibatkan asesmen lebih dalam.

\section{Metode}

\section{Subjek}

Penelitian ini dilakukan secara acak yang dikirim melalui online, di mana subjek dapat mengisi survei melalui link yang telah disediakan oleh peneliti. Link ini dapat diakses dari berbagai daerah di Indonesia. Adapun subjek yang terlibat dalam penelitian ini, yaitu:

1. Berusia di atas 20 tahun

2. Dapat membaca tulisan berbahasa Indonesia

3. Dapat mengaplikasikan teknologi

4. Tinggal di Indonesia

\section{Desain penelitian}

Penelitian ini dilakukan secara kuantitatif. Aliaga dan Gunderso (2002) menjelaskan bahwa penelitian kuantitatif sebagai metode eksplorasi sebuah isu atau fenomena kedalam sebuah angka dan dianalisa secara matematik, khususnya statistik. Bentuk metode yang digunakan berupa metode korelasi, yaitu menguji hubungan dua atau lebih variabel dalam suatu populasi (sampel). Derajat hubungan dinilai berdasarkan nilai koefisien korelasi statistik (Apuke, 2017).

\section{Variabel Penelitian}

Penelitian ini melibatkan dua variabel penelitian, yaitu:

Variabel bebas : Distress

Variabel tergantung : Obsesive Compulsive Disorder

\section{Pengukuran}

Alat tes yang digunakan dalam penelitian ini, yaitu:

1. Hopkins Symptom Checlist 25 (HSCL)

HSCL 25 merupakan salah satu bentuk laporan diri (self report) yang bertujuan untuk mengetahui kondisi distress seseorang, melalui simtom depresi dan kecemasan. HSCL 25 dikembangkan oleh Rickels dengan didasarkan pada HSCL asli yang didesain oleh Parloff, Kelmam, dan Frank. HSCL yang digunakan dalam penelitian ini terdiri atas 25 item, yang terdiri atas: item 1-10 simtom kecemasan dan item 11-25 simtom depresi. 
Cut off dari masing-masing simtom yaitu 1,75. Apabila seseorang memiliki skor di atas 1,75 berarti orang mengalami distress (APA, 2000).

2. Yale Brown OCD Scale (YBOCS)

YBOCS merupakan skala untuk mengukur prevalensi OCD pada seseorang. Skala ini dirancang oleh Wayne K. Goodman dkk (1989). YBOCS terdiri atas 10 item (5 item obsesi dan 5 item kompulsif) prosentase OCD. Penilaian pada 10 item terdiri dari skor 0 4. Selanjutnya dikategorikan berdasarkan nilai total. Skor $8-15=0$ OCD ringan; $16-23=$ OCD sedang; $24-31=$ OCD berat; dan $32-40=$ OCD parah.

YBOCS juga dilengkapi dengan self-report terkait jenis obsesi dan kompulsif yang muncul sebagai bentuk identifikasi OCD yang dialami. Self-Report ini difokuskan pada bentuk obsesi berupa kontaminasi, serta kompulsif berupa kebersihan. Self-Report ini hanya menggunakan jawab "Ya" dan "Tidak, yang terdiri dari 12 item (Obsesif = 8 item dan Kompulsif $=4$ item)

\section{Analisis Data}

Data yang telah dikoding atau dinilai ke dalam Microsoft Excel selanjutnya dianalisa melalui program SPSS versi 25. Peneliti menggunakan product moment correlation from Pearson sebagai cara Analisa datanya.

\section{Proses Penelitian}

Penelitian ini dilakukan secara online dan acak. Subjek diminta untuk melaporkan kondisi psikologis mereka melalui sebuah link : bit.ly/PsikologMenyapa. Link disebarkan melalui WhatsApp. Link ini (bit.ly/PsikologMenyapa) berisi skala distress (HSCL) dan skala OCD (YBOCS). Sebelum mengisi skala, setiap subjek diharuskan mengisi identitas diri dan melakukan klik tanda centang sebagai bentuk persetujuan. Data kolektif akan disimpan secara otomatis dan online di dalam Google Form. Peneliti selanjutnya melakukan penilaian atau koding ke dalam Microsoft Excel sebelum dianalisa menggunakan program statistik.

\section{Hasil}

Penelitian ini diikuti oleh 157 subjek (119 wanita dan 38 laki-laki), dimana masingmasing subjek diminta untuk mengisi data pribadi dan 2 skala yang menjadi variable penelitian ini. Berikut adalah hasil dari skala yang telah diisi oleh seluruh subjek: 


\begin{tabular}{llr|r}
\multicolumn{3}{c}{ Correlations } \\
& \multicolumn{1}{c}{ OCD } & Distress \\
\hline OCD & Pearson Correlation & 1 &, $998^{* *}$ \\
\cline { 2 - 4 } & Sig. (2-tailed) & &, 000 \\
\cline { 2 - 4 } & $\mathrm{N}$ & 157 & 157 \\
\hline Distress & Pearson Correlation &, $998^{* *}$ & 1 \\
\cline { 2 - 4 } & Sig. (2-tailed) &, 000 & \\
\cline { 2 - 3 } & $\mathrm{N}$ & 157 & 157 \\
\hline$* *$ Correlation is significant at the 0.01 level (2- \\
tailed).
\end{tabular}

Hasil analisis data penelitian (Gambar 1) menunjukkan angka korelasi sebesar 0.998 dan 0,000 pada kolom Sig. (2-tailed). Angka sig. ini < 0,05 sehingga menunjukkan adanya signifikansi dan adanya korelasi positif antara distress dan OCD selama masa pandemic Covid 19. Hal ini berarti semakin tinggi skor distress, maka semakin tinggi pula skor OCD yang dimiliki seseorang.

\section{Diskusi}

Hasil penelitian menunjukkan bahwa hipotesa yang diajukan dalam penelitian ini diterima. Seseorang yang memiliki distress tinggi memiliki potensi untuk memiliki OCD akibat covid 19. Badri (2020) menjelaskan bahwa seseorang bisa berpotensi mengalami gangguan phobia sosial dan OCD sebagai bentuk akibat distress yang berkepanjangan selama pandemik Covid 19.

Pada penelitian ini ditemukan 90 subjek (57,3 \%) mengalami distress selama pandemik Covid 19. Hasil yang serupa juga ditemukan oleh Wang dkk (2020) ketika melakukan penlitian di Wuhan. Orang-orang yang tinggal di daerah terpapar virus memiliki skor distress yang tinggi daripada yang tidak tinggal disana. Selain itu, pemberitaan media masa dalam melaporkan covid 19 juga berpengaruh terhadap skor distress. Bentuk distress yang muncul akibat covid 19 diantaranya: masalah tidur, ketakutan terhadap virus, susah fokus, cemas, dan depresi (Wang dkk, 2020)

Barber dkk (2020) menyatakan bahwa kecemasan dan depresi merupakan gangguan mental terbesar yang diakibatkan oleh Covid 19. Selain itu, kecemasan dan depresi juga dapat menjadi komorbid munculnya OCD (Koran dkk, 2007; Moore \& Howell, 2017; Moroney, 2017; Pigot dkk, 1994). Kondisi ini serupa dimana kecemasan dan depresi merupakan aspek distress yang diukur dengan menggunakan HSCL-25 dan terbukti keduanya memiliki skor yang tinggi.

Pada penelitian ini ditemukan pula dimana skor distress juga berpengaruh dengan skor OCD. Pandemik Covid 19 dapat memicu munculnya OCD. Orang-orang yang memiliki level 
distress yang tinggi terbukti secara signifikan menunjukkan kekhawatiran terhadap virus, kuman dan kotoran dibandingkan orang-orang yang memiliki level distress rendah. Orangorang yang memiliki skor distress tinggi cenderung kompulsif dalam mencuci tangan daripada yang orang-orang yang memiliki skor distress rendah (Aji dkk, 2020).

Penelitian ini memiliki keterbatasan yaitu jumlah subjek yang masih terhitung sangat sedikit. Roscoe (dalam Sekaran, 2013) menyatakan bahwa sampel penelitian dikatakan efektif apabila berjumlah lebih dari 30 dan kurang dari 500. Akan tetapi menurut Lemeshow (1997) penelitian dengan jumlah populasi yang sangat besar sebaiknya peneliti perlu menghitung jumlah target sampel. Jumlah target minimal dapat diperoleh dengan cara menggunakan rumus slovin. Jumlah sampel yang rendah akan dianggap tidak dapat mewakili data dari populasi yang ada.

\section{Kesimpulan dan Saran}

\section{Kesimpulan}

Di Indonesia, Covid 19 dapat menyebabkan distress sehingga membuat seseorang berpotensi mengalami OCD.

\section{Saran}

\section{A. Bagi peneliti selanjutnya}

1. Peneliti bisa melakukan penelitian lebih mendalam dalam melakukan asesmen sehingga diagnosa OCD dapat ditegakkan.

2. Penelitian dilakukan secara lebih detil mengenai distress dan OCD untuk menguji perbedaan berdasarkan jenis kelamin.

3. Penelitian eksperimen dengan melibatkan satu variable control (psikoterapi) dapat menjadi studi pendahuluan sebagai salah satu upaya kuratif.

\section{B. Bagi Praktisi}

1. Pertolongan pertama psikologis saat ini sangat dibutuhkan oleh masyarakat dalam mengatasi distress. Pertolongan pertama ini dapat dilakukan secara online atau langsung (tatap muka).

2. Psikoedukasi tentang kesehatan mental selama masa pandemik Covid 19 perlu dilakukan sebagai bentuk upaya promotif.

\section{Bagi Masyarakat}


Masyarakat dapat segera meminta pertolongan kepada pihak professional (psikolog dan dokter) apabila mengalami permasalahan kesehatan mental, khususnya distress dan OCD

\section{Daftar Pustaka}

Abba-Aji, A., Li, D., Hrabok, M.,.., \& Agyapong, V.I.O., (2020). Covid-19 Pandemic and Mental Health: Prevalence and Correlates of New-Onset Obsessive-Compulsive Symptoms in a Canadian Province. Doi: 10.2196/preprints.19648

Aliaga, M. \& Ganderson, B., (2002). Interactive Statistics. Thousand Oaks: Sage Publications

American Psychiatric Association (APA) (2000). Diagnostic and statistical manual of psychiatric disorders (4th-TR, ed.). Washington, DC: American Psychiatric Association (APA).

Apuke, O.D., (2017), Quantitative Research Methods: A Synopsis Approach. Arabian J Bus Manage Review (Kuwait Chapter). Vol. 6(10). Doi: 10.12816/0040336

Badri, M. (2020, 06 Juni). IIIT Intellectual Discourse Series: Is Mental Illness The Next Wave Of Covid-19 Pandamic. Youtube.com. Diunduh tanggal 30 Juni 2020 dari: https://www.youtube.com/watch?v=J6ylA0Yu6nE

Barber, S., Reed, L., Syam, N., \& Jones, N., (2020). Severe mental illness and risk from COVID - 19. Didownload : https://www.cebm.net/covid-19/severe-mental-illness-and-risks-fromcovid-19/ tanggal 11 Agustus 2020

Brooks, S.K., Webster, R.K., Smith, L.E., Woodland, L., Wessely, S., Greenberg, N., Rubin, G.J., (2020), The psychological impact of quarantine and how to reduce it: rapid review of the evidence. The Lancet. 395: 912 - 920. doi : 10.1016/S0140-6736(20)30460-8

COVID-19 Corona virus oubreak. Diunduh dari : https://www.worldometers.info/coronavirus/ tanggal 01 Juli 2020

Feng, L., Dong,Z., Yan, R., Wu., Zhang, Li, Ma, J., (2020). Psychological distress in the shadow of the Covid-19 pandemic: Preliminary development of an assesment scale. Psychiatry Research. 291. http://doi.org/10.1016/j.psychres.2020.113202

Goodman, W.K., Price, L.H., Rasmussen, S.A., Mazure, C., dkk., (1989). The Yale - Brown Obsessive Compulsive Scale.I. Development, use, and realibility. Arch Gen Psychiatry 46 (11): 1006 - 1011 doi: 10.1001/archpsyc.1989.01810110048007.

Koran, L.M., Hanna, G.L., Hollander, E., Nestadt, G., \& Simpson, H.B., (2007). Practice guideline for the treatment of patients with obsessive-compulsive disorder. The American Journal of Psychiatry, 164, 5-53.

Lemeshow, S. \& David W.H.Jr, 1997. Besar Sampel dalam Penelitian Kesehatan (terjemahan), Gadjahmada University Press, Yogyakarta

Mazza, C., Ricci, E., Biondi, S., ..., \& Roma, P., (2020), A Nationwide Survey of Psychological Distress among Italian People during the COVID-19 Pandemic: Immediate Psychological Responses and Associated Factors. Int. J. Environ. Res. Public Health, 17, 3165, doi : 10.3390/ijerph17093165 
Moore, K.A. \& Howell, J., (2017). Yes: The Symptoms of OCD and Depression are Discrete and not exclusively negative affectivity. Frontiers in Psychology, 8: 753, doi: 10.3389/fpsyg.2017.00753

Moroney, K., (2017)., The Relationship Between Obsessive-Compulsive Disorder and Depression in the General Population. Senior Honors Theses. Michigan: Eastern Michigan University.

Nevid, J. S., Rathus, S. A., dan Greene, B. 2005. Psikologi Abnormal Jilid 1 (Terjemahan) Jakarta : Penerbit Erlangga.

Perrin, P.C., McCabe, L., Everly, G.S., \& Link, J.M., (2009). Preparing for an influenza pandemic: Mental health considerations. Prehospital and Disaster Medicine. 25(3): 223-230. doi : $10.1017 / \mathrm{s} 1049023 \times 00006853$

Pigot, T.A., L'Heureux, F., Dubbert, B., Bernstein, S., \& Murphy, D.L., (1994). Obsessive compulsive disorder: Comorbid conditions. J Clin Psychiatry, 55, 15-32.

Sekaran, U. (2013). Metodologi Penelitian untuk Bisnis. Jakarta: Salemba empat

Tirto, A.R., Turnip, S.S., (2019). The Accuracy of Hopkins Symptom Checlist - 25 (HSCL-25) depression subscales (Indonesian Version) on Adolescent. Humanitas Indonesian Psychological Journal. Vol.16. No. 1. Febuary 2019, 1-12

Wang, H., Xia, Q., Xiong, Z., Li, Z., Xiang, W., Yuan, Y., Liu, Y., Li., (2020). The psychological distress and coping styles in the early stages of the 2019 coronavirus disease (COVID-19) epidemic in the general mainland Chinese population: A web-based survey, Plos One, 15 (5). Diunduh dari: https://doi.org/10.1371/journal.pone.0233410 pada tanggal : 18 Agustus 2020.

Wheaton, B. (2007). The twain meets: distress, disorder and the continuing conundrum of categories (comment on Horwitz). Heatlh no. 11:303-319 